\title{
The Influence of Training, Empowerment, and Organizational Commitment on Employee Performance at PT Rachmat Jaya Sejati Gresik
}

\author{
Siti Sholihatun Mukaromah ${ }^{1}$, I Putu Artaya, SE. MM² \\ Narotama University, Surabaya \\ s.muharroma@yahoo.com
}

\begin{abstract}
The purpose of this study is to analyze training, empowerment, and organizational commitment on employee performance at PT Rachmat Jaya Sejati Gresik. This research is using quantitative methode. The population and sample are 35 employees at PT Rachmat Jaya Sejati Gresik. Data retrieval technique is by distributing questionnaires. In this study using SPSS version 16.0 software and multiple linear regression analysis. The results showed that training has a significant effect of $53.9 \%$ on the employee performance; empowerment has not a significant effect of $11.8 \%$; organizational commitment has a significant effect of $36.7 \%$. In simultaneous, training, empowerment, and organizational commitment had a significant effect of $94 \%$. so, there are a number of suggestions for companies to maintain and improve organizational training and commitment. Especially for empowerment, companies must improve empowerment such as more involving and paying attention to employee opinions in solving problems.
\end{abstract}

Keywords: Training, Empowerment, Organizational Commitment, Employee Performance

\section{INTRODUCTION}

Times are growing, not only on land transportation. However, maritime lane transportation also experiences the same thing. This is certainly a trigger for companies to be able to maintain the company's vital assets owned in order to quickly respond to changes that occur, because the role of humans cannot be replaced by other resources. This is supported by the opinion of Ardana, 2012:15 (Dewi \& Suwandana, 2016), human resources are the potential strengths and capabilities possessed by companies that are used to carry out technical and managerial activities within the organization to fulfill the objectives of the organization. To meet organizational goals can be determined through good or bad employee performance. Employee performance is the ability of employees to do certain skills Lijan Poltak Sinambela et al, 2011:136 (Sinambela, 2012). According to Mangkunegara (2000) (Noermijati, 2013)which suggests performance is the work result in quality and quantity achieved by an employee in carrying out his duties in accordance with the responsibilities given to him. According to Mathis and Jackson (2006:378) (Kahpi, Khurosaini, \& Suhendra, 2017)there are indicators in employee performance, is: a. Quantity is the employee's perception of the number of activities assigned and the results b. Quality is the employee's perception of the quality of work produced and the task's perfection of the skills and abilities of employees. c. Timeliness, namely the employee's perception of an activity completed from the beginning of time until it becomes output. $d$. Effectiveness is the maximum utilization of resources and time in the organization to increase profits and reduce losses. e. Presence, namely the level of attendance

The Influence of Training, Empowerment, and Organizational Commitment on Employee Performance at PT Rachmat Jaya Sejati Gresik

Siti Sholihatun Mukaromah, I Putu Artaya, SE. MM 
of employees in the company can determine employee performance. There are many factors that can affect employee performance including training, empowerment and organizational commitment.

The many changes that have occurred, PT Rachmat Jaya Sejati has also innovated by implementing a new online system called Inaport. Inaport is an online system that handles licensing processes in ship agency activities operating in ports / pelindo. Employees must be able to carry out the inaport operation process in accordance with the procedure. Therefore, an effort is needed to improve the knowledge and skills of employees in running Inaport. One of them is training. Training is a series of activities designed to improve skills, knowledge, experience, or changes in one's attitude (Simamora, 2001:345) (Sinambela, 2012). According to (Rivai and Sagala, 2013, p. 226) (Tanujaya, 2015) there are indicators in training, is: quality of training materials, quality of training methods, quality of training instructors, quality of training facilities and facilities, and quality of training participants. Because according to (Noe, 2012) (Ataunur \& Ariyanto, 2015) Training can help employees develop a variety of specific skills that enable them to succeed in their current work and develop their work in the future.

PT. Rachmat Jaya Sejati still found work that had not been completed as expected. So the company develops human resources to improve the performance of its employees. One of the development efforts that can be done by the company is through empowering its employees. Empowerment is defined by (Greenberg and Baron, 2003:448) (Wibowo, 2007) is a process where workers are given an increase in a number of autonomy and freedom in relation to their work. According to (Kadarisman, 2013:269) (Pratama \& Sriathi, 2015) there are indicators in empowerment, is: a. Desire is the desire of management to delegate and involve employees $b$. Trust is the desire of management to empower, the next step is to build entrepreneurship between management and employees c. Confident is after the existence of mutual trust can lead to employee confidence by respecting the capabilities possessed by employees $d$. Creadibility is maintain credibility by appreciation and develop a work environment that supports healthy competition so that organizations that have high performance are created e. Accountability is employee responsibility for the authority granted and $\mathrm{f}$. Communication is the existence of open communication to create mutual understanding between employees and management. Because according to (Smith, 2001) (Wibowo, 2007) empowering people means encouraging them to become more involved in decisions and activities that affect their work.

PT Rachmat Jaya Sejati Gresik still finds employees who are late at work. The management of PT Rachmat Jaya Sejati Gresik believes that employee commitment to the company is still lacking. Because employees are considered less concerned with company affairs. So that the management of PT Rachmat Jaya Sejati Gresik seeks to change the negative behavior of employees who are still late by piling up employees' commitment to the company. Organizational commitment is the degree to which employees believe in and accept organizational goals and desire to remain with the organization (Mathis and Jackson, 2000) (Utaminingsih, 2014). According to (Luthans, 2006:249) (Widayanti \& Sariyathi, 2016) expressing the opinion that as an attitude, organizational commitment is often defined as an attitude that reflects employee loyalty to the organization and ongoing processes in which members of the organization express their concern for the organization and success and continuous progress. According to (Kuo et al, 2010) (Widayanti \& Sariyathi, 2016) there are indicators in organizational commitment, is: a. Affective Commitment, refers to the extent of the employee's emotional relationship with the organization $b$. Continuance Commitment, refers to the extent to which employees have an association with the organization so that employees will feel loss if they leave the organization and c. Normative Commitment, refers to the extent to which employees feel obligatory and responsible for continuing their work in the organization.

In the case, the results of various previous studies in the from of findings and theories can be used as a basis or reference and supporting data that are relevant to the problems related to this research.

Y. K. Marga (Marga, 2016) in her research entitled The Effect of Training, Emotional Intelligence and Organizational Culture on Employee Performance of PT Surabaya Tempuran Emas found the results

The Influence of Training, Empowerment, and Organizational Commitment on Employee Performance at PT Rachmat Jaya Sejati Gresik

Siti Sholihatun Mukaromah, I Putu Artaya, SE. MM 
of the study stating that the independent variables of training partially had a significant effect on employee performance. Emotional intelligence partially has a significant effect on employee performance. Partial organizational culture has a significant effect on employee performance. Training, emotional intelligence, and organizational culture together can explain the ups and downs of employee performance. But this is different from E. S. Pakpahan, Siswidiyanto, and Sukanto (Pakpahan, Siswidiyanto, \& Sukanto, 2003) in his research entitled The Effect of Education and Training on Employee Performance (Study in the Regional Civil Service Agency of Malang City) found the results of the study stating that the Education and Training variables jointly had a significant effect on performance while training does not have a significant effect on employee performance.

U. T. Cahyono, M. S. Maarif, and Suharjono (Cahyono, Maarif, \& Suharjono, 2014) in his research entitled The Effect of Transformational Leadership on Employee Performance in Jember Regional Plantation Companies with the results of research stating that transformational leadership has a significant and positive effect on the empowerment of PDP Jember employees, transformational leadership has a significant and positive influence on the work of PDP Jember employees, transformational leadership has no significant and positive effect on employees of PDP Jember, empowerment is not significant and positive effect on the performance of PDP Jember employees, PDP Jember. But this is different from A. V. Putri and I. K. Ardana (Putri \& Ardana, 2016) in his research entitled The Effect of Employee Motivation and Empowerment on Employee Performance at PT HD Motor 99 Denpasar with the results of research that states that motivation has a positive and significant effect on performance. Employee empowerment has a positive and significant effect on employee performance.

S. W. Putra (Putra, 2015) in his research entitled The Effect of Organizational Commitment, Organizational Culture, Leadership Style and Environment on Employee Performance in Small Industries with the results of research that stated that organizational commitment, organizational culture, leadership and the physical environment simultaneously affect employee performance. While for the partial test shows that organizational commitment affects employee performance, organizational culture influences employee performance, leadership and the physical environment influence employee performance. But this is different from Sunarno and L. Liana (Sunarno \& Liana, n.d.) in his research entitled The Effect of Organizational Commitment and Organizational Culture on Teacher Performance Mediated at Job Satisfaction (Case Study of Kesatrian High School Teachers in the Kesatrian Education Foundation 67) with research results stating that organizational commitment does not affect job satisfaction, organizational culture influences teacher job satisfaction. Job satisfaction affects teacher performance significantly. Job satisfaction does not mediate the effect of organizational commitment on teacher performance. Mediation test results of job satisfaction on the influence of organizational culture on teacher performance, organizational culture (X2) significantly influence teacher performance (Y2). While job satisfaction does not mediate organizational culture on teacher performance.

Based on the results of the empirical study above, the gaps in the research are the existence of research on training, empowerment, and organizational commitment that does not significantly affect employee performance, which should be training, empowerment, and organizational commitment play a role in employee performance. Therefore the scribbled writer is to re-examine employee performance as measured by training, empowerment, and organizational commitment variables.

\section{METHODOLOGY}

This study uses a quantitative approach with independent variables training, empowerment, and organizational commitment as well as employee performance dependent variables.

The Influence of Training, Empowerment, and Organizational Commitment on Employee Performance at PT Rachmat Jaya Sejati Gresik

Siti Sholihatun Mukaromah, I Putu Artaya, SE. MM 


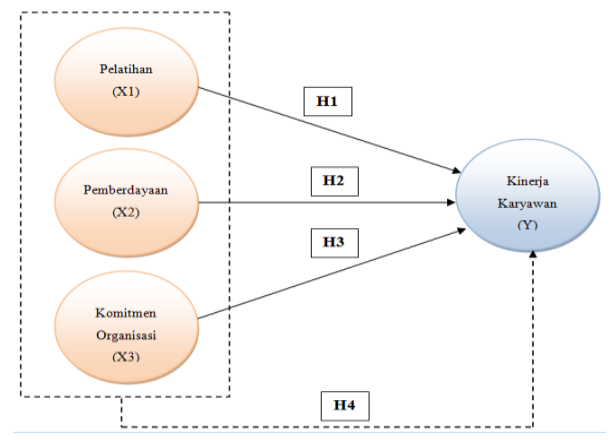

Figure 1. Conceptual Framework

This study uses a population and sample are 35 employees at PT Rachmat Jaya Sejati Gresik. This research has data sources namely primary data and secondary data. Primary data in this study was obtained by distributing questionnaires to all employees of PT Rachmat Jaya Sejati. Secondary data used in this study comes from company profile, employee data, books and journals related to research variables. Data analysis techniques in this study used validity and reliability, normality test, multicollinearity test, heterocedasticity test, autocorrelation test, $\mathrm{F}$ test, $\mathrm{T}$ test and coefficient of determination $\left(\mathrm{R}^{2}\right)$ tested using SPSS version 16.0 software and multiple linear regression analysis.

The multiple linear regression models used are as follows:

$$
\mathrm{Y}=\mathrm{a}+\mathrm{bX} 1+\mathrm{bX} 2+\mathrm{bX} 3+\mathrm{e}
$$

$\mathrm{Y}$

: employee performance

: constant

b1,b2,b3

: regression coefficient

$\mathrm{X} 1$

: training variable score

$\mathrm{X} 2$

: variable empowerment score

$\mathrm{X} 3$

: variable score of organizational commitment

e

: error estimate

\section{RESULT AND DISCUSSION}

\section{Reliability and Validity}

Based on the research shows that the value of alfa cronbanch is 0.949 , which means that it is above acceptance limit of 0.6 , therefore, the research instrument for relationship among the variable indicates good consistency and the data is acceptable. Based on research value of correlation index for relationship among variable independents (training, empowerment and organizational commitment) with variable dependent (employee performance) are greater than 0.3 and below the significant level of 5\% $(0.05)$. The correlation between training (0.963), empowerment $(0.926)$, and organizational commitment

The Influence of Training, Empowerment, and Organizational Commitment on Employee Performance at PT Rachmat Jaya Sejati Gresik

\section{Siti Sholihatun Mukaromah, I Putu Artaya, SE. MM}


(0.912) with employee performance (1.000) show a positive known. Therefore, the data is considered as valid.

\section{Multiple Linear Regression}

Table 1. The Results of Multiple Linear Regression

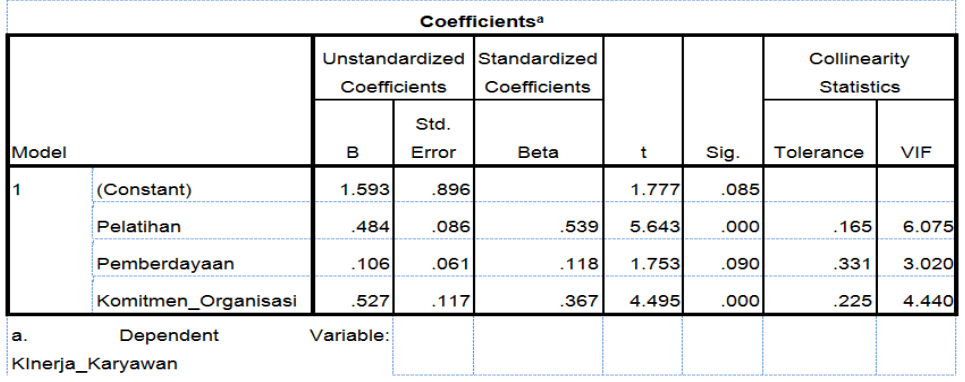

Source: SPSS Output, 2019

The multiple regression model in this study can be shown as follows:

$$
\begin{gathered}
\mathrm{Y}=\mathrm{a}+\mathrm{bX} 1+\mathrm{bX} 2+\mathrm{bX} 3+\mathrm{e} \\
\mathrm{Y}=1.593+0.484 \mathrm{X} 1+0.106 \mathrm{X} 2+0.527 \mathrm{X} 3+\mathrm{e}
\end{gathered}
$$

The above equation has meaning, namely :

1. The constant $(\alpha)$ of 2.018 shows that the effect on the relationship between the variables Training (X1), Empowerment (X2), and Organizational Commitment (X3) with Employee Performance (Y), means that if all the independent variables are zero, then Employee performance $(\mathrm{Y})$ is estimated to be 1.593

2. If the others are constant, a one-point increase in Training (X1) will result in an average increase of at least 0.539 in Employee Performance (Y)

3. If the others are constant, a one-point increase in Empowerment (X2) will result in an average increase of at least 0.118 in Employee Performance (Y)

4. If the others are constant, a one-point increase in Organizational Commitment (X3) will result in an average increase of at least 0.367 in Employee Performance (Y)

\section{The Result of R Square}

Table 2. The Result of R Sauare

\begin{tabular}{|l|r|r|r|r|r|}
\hline \multicolumn{9}{|c|}{ Model Summary } \\
\hline Model & $\mathrm{R}$ & $\mathrm{R}$ Square & $\begin{array}{c}\text { Adjusted R } \\
\text { Square }\end{array}$ & $\begin{array}{c}\text { Std. Error of the } \\
\text { Estimate }\end{array}$ & Durbin-Watson \\
\hline 1 & .976 & .954 & .949 & .50119 & 1.730 \\
\hline
\end{tabular}

a. Predictors: (Constant). Komitmen_Organisasi. Pemberdayaan. Pelatihan

b. Dependent Variable: KInerja_Karyawan

The Influence of Training, Empowerment, and Organizational Commitment on Employee Performance at PT Rachmat Jaya Sejati Gresik

\section{Siti Sholihatun Mukaromah, I Putu Artaya, SE. MM}


The value of $\mathrm{R}$ Square is 0.954 , this shows that all independent variables: Training, Empowerment, and Organizational Commitment have a positive relationship with Employee Performance.

\section{Test of Classical Assumption}

\section{The Result of Multicollinearity}

Table 3. The Result of Multicollinearity

\begin{tabular}{|c|c|c|c|c|c|c|c|c|}
\hline \multicolumn{9}{|c|}{ Coefficients ${ }^{a}$} \\
\hline \multirow[b]{2}{*}{ Model } & & \multicolumn{2}{|c|}{$\begin{array}{c}\text { Unstandardized } \\
\text { Coefficients }\end{array}$} & \multirow{2}{*}{\begin{tabular}{|c|}
$\begin{array}{c}\text { Standardized } \\
\text { Coefficients }\end{array}$ \\
Beta \\
\end{tabular}} & \multirow[b]{2}{*}{$\mathrm{t}$} & \multirow[b]{2}{*}{ Sig. } & \multicolumn{2}{|c|}{$\begin{array}{l}\text { Collinearity } \\
\text { Statistics }\end{array}$} \\
\hline & & B & $\begin{array}{l}\text { Std. } \\
\text { Error }\end{array}$ & & & & Tolerance & VIF \\
\hline 1 & (Constant) & 1.593 & .896 & & 1.777 & .085 & & \\
\hline & Pelatinan & .484 & .086 & .539 & 5.643 & .000 & .165 & 6.075 \\
\hline & Pemberdayaan & .106 & .061 & .118 & 1.753 & .090 & .331 & 3.020 \\
\hline & Komitmen_Organisasi & .527 & 117 & .367 & 4.495 & .000 & .225 & 4.440 \\
\hline $\begin{array}{l}\text { a. } \\
\text { KInerja }\end{array}$ & $\begin{array}{l}\text { Dependent } \\
\text { Karyawan }\end{array}$ & Variable: & & & & & & \\
\hline
\end{tabular}

Source: SPSS Output, 2019

Training tolerance is 0.165 , Empowerment is 0.331 , and organizational commitment is 0.225 which means that the tolerance value of each variable is more than 0.1 . The VIF value of the training is 6.075 , empowerment is 3.020 , and organizational commitment is 4.440 , indicating that the value of the three variables is less than 10. Because the tolerance value is more than 0.1 and the VIF value is less than 10 studies are free from multicollinearity.

\section{The Result of Heteroscedasticity}

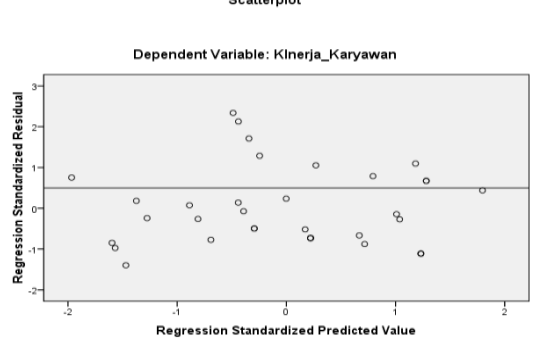

The Influence of Training, Empowerment, and Organizational Commitment on Employee Performance at PT Rachmat Jaya Sejati Gresik

Siti Sholihatun Mukaromah, I Putu Artaya, SE. MM 
Figure 2. The Result of Heteroscedasticity

Source : Data Processed, 2019

The pattern of dots spreads and does not make a clear pattern. The points spread above and below 0 (zero) at $\mathrm{Y}$ and that proves that the model is free from heteroscedasticity.

\section{The Result of Normality}

Normal P.P Plot of Regression Standardized Residual

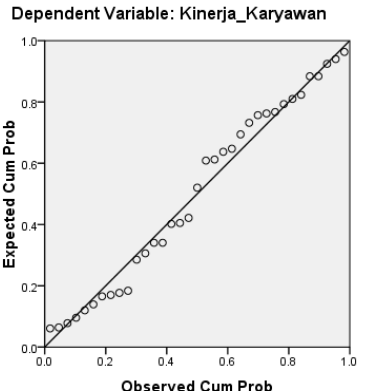

Figure 3. The Result of Normality

Source : Data Processed, 2019

Data that spreads near the diagonal line and follows the direction of the diagonal line. This proves that the model has passed the normality test.

\section{Hypothesis Testing}

\section{F-Test}

Table 4. The Result of F-test

\begin{tabular}{|l|l|r|r|r|c|c|}
\hline \multicolumn{7}{|c|}{ ANOVAD $^{\text {Model }}$} \\
\hline 1 & Regression & Sum of Squares & df & Mean Square & F & Sig. \\
\hline & Residual & 159.756 & 3 & 53.252 & 211.996 & .0000 \\
& Total & 7.787 & 31 & .251 & & \\
\hline
\end{tabular}

a. Predictors: (Constant), Komitmen_Organisasi, Pemberdayaan, Pelatihan

b. Dependent Variable: KInerja_Karyawan

The Influence of Training, Empowerment, and Organizational Commitment on Employee Performance at PT Rachmat Jaya Sejati Gresik

\section{Siti Sholihatun Mukaromah, I Putu Artaya, SE. MM}


This test is done by comparing the $\mathrm{F}$ count value with $\mathrm{F}$ table value at $\alpha=0.05$. The overall effect of Training (X1), Empowerment (X2), and Organizational Commitment on Employee Performance $(\mathrm{Y})$ is very significant.

\section{T-Test}

Table 5. The Result of T-test

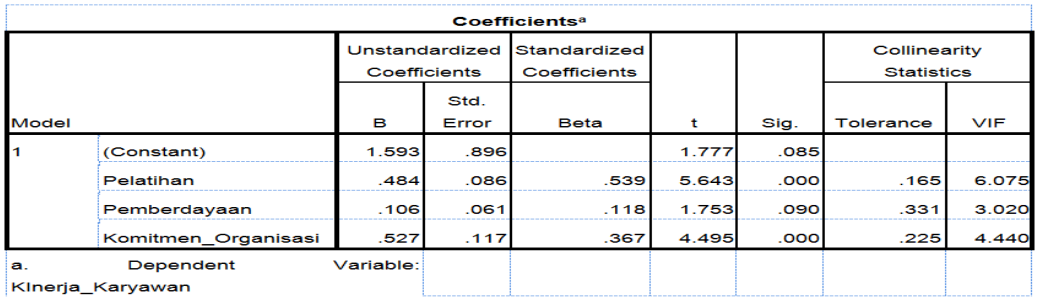

Source: SPSS Output, 2019.

1. The hypothesis that reject $\mathrm{H} 0$ and accept $\mathrm{Ha}$ if $\mathrm{t}$ count $\geq \mathrm{t}$ table or accept $\mathrm{H} 0$ and reject $\mathrm{Ha}$ if $\mathrm{t}$ count $\geq \mathrm{t}$ table. $\mathrm{T}$ count training (X1) is 5.643 . Comparing t count with $\mathrm{t}$ table: $5.503 \geq 1.688$. Because $t$ count is greater than $\mathrm{t}$ table, $\mathrm{H} 0$ is rejected and $\mathrm{H} 2$ is accepted. Therefore, training has a significant influence on employee performance.

2. The hypothesis is to reject $\mathrm{H} 0$ and accept $\mathrm{H} 3$ if $t$ counts $\geq t$ table or accept $\mathrm{H} 0$ and reject $\mathrm{H} 3$ if $t$ count $\geq \mathrm{t}$ table. $\mathrm{T}$ count empowerment $(\mathrm{X} 2)$ is 1.753 . Comparing $\mathrm{t}$ count with $\mathrm{t}$ table: $1.753 \leq$ 2.039. Because $t$ count is smaller than t table, $\mathrm{HO}$ is accepted and $\mathrm{Ha}$ is rejected. Therefore, empowerment has not a significant effect on employee performance.

3. The hypothesis is to reject $\mathrm{HO}$ and accept $\mathrm{H} 3$ if $t$ counts $\geq t$ table or accept $\mathrm{H} 0$ and reject $\mathrm{H} 3$ if $t$ count $\geq \mathrm{t}$ table. $\mathrm{T}$ count organizational commitment (X3) is 4.495 . Comparing $\mathrm{t}$ count with $\mathrm{t}$ table: $4.495 \geq 2.039$. Because $t$ count is greater than $\mathrm{t}$ table, $\mathrm{H} 0$ is rejected and $\mathrm{Ha}$ is accepted. Therefore, organizational commitment has a significant influence on employee performance

\section{DISCUSSION}

H1: Training on Employee Performance

The results of the training hypothesis testing have a significant effect on employee performance. The results of the first hypothesis test prove the value of Sig. amounting to 0.000 with a t value of 5.643. This value is greater than $t$ table (2.039) and Sig. below 0.05. This shows that employees have received effective training provided by the company. So that employee performance also increases.

H2: Empowerment of Employee Performance

The results of testing the empowerment hypothesis have no significant effect on employee performance. The second hypothesis test results prove the value of Sig. amounting to 0.090 with at value of 1.753. This value is smaller than t table (2.039) and Sig. above 0.05. This shows that employees have not fully felt the empowerment that has been implemented by the company. So that empowerment has not been able to influence employee performance.

H3: Organizational Commitment to Employee Performance

The Influence of Training, Empowerment, and Organizational Commitment on Employee Performance at PT Rachmat Jaya Sejati Gresik

Siti Sholihatun Mukaromah, I Putu Artaya, SE. MM 
The results of hypothesis testing of organizational commitment have a significant effect on employee performance. The third hypothesis test results prove the value of Sig. amounting to 0.000 with a $t$ value of 4.495. This value is greater than $t$ table (2.039) and Sig. below 0.05. This shows that employees have a high commitment to the organization. So that employee performance increases.

\section{CONCLUSION AND RECOMMENDATION}

\section{Conclusion}

Based on the results of the research and analysis that has been done can be concluded several conclusions, that :

1. Training has a significant effect on employee performance, this means that if effective training increases it will improve employee performance.

2. Empowerment has not a significant effect on employee performance, this means that the empowerment implemented by the company has not been fully able to improve employee performance

3. Organizational commitment has a significant effect on employee performance, this means that if the Organizational Commitment is high it will improve employee performance.

4. In simultaneous consisting of Training, Empowerment and Organizational Commitment jointly influence Employee Performance.

\section{Recommendation} suggestions :

Based on the results of the research and conclusions above, the researcher gives the following

1. The company still has to pay attention to the needs of its employees. So the company can provide effective training for employees in need. The companies must maintain and further improve the effectiveness of the training provided.

2. Empowerment is proven to have no significant effect on employee performance. This is certainly a concern for the company. The company must evaluate and improve the implementation of empowerment. Companies should involve employees more in solving problems that occur and pay attention to employee opinions.

3. Companies still have to strive for foster employee commitment to the organization. So that the company can be a priority for employees. The companies must maintain and further enhance employee commitment to the organization.

\section{REFERENCES}

Ataunur, I., \& Ariyanto, E. (2015). Pengaruh Kompetensi dan Pelatihan Terhadap Kinerja Karyawan PT Adaro Energy Tbk. Telaah Bisnis, 16(2), 135-150.

Cahyono, U. T., Maarif, M. S., \& Suharjono. (2014). Pengaruh Kepemimpinan Transformasional Terhadap Kinerja Karyawan di Perusahaan Daerah Perkebunan Jember. Jurnal Manajemen \& Agribisnis, 11(2), 68-76.

Dewi, I. G. A. S., \& Suwandana, I. G. Ma. (2016). Pengaruh Pemberdayaan Karyawan, Komitmen Organisasional dan Kompensasi Finansial Terhadap Kepuasan Kerja Karyawan. E-Jurnal Manajemen Unud, 5(4), 1969-1997.

Kahpi, H. S., Khurosaini, A., \& Suhendra, I. (2017). Pengaruh Pelatihan dan Motivasi Berprestasi

The Influence of Training, Empowerment, and Organizational Commitment on Employee Performance at PT Rachmat Jaya Sejati Gresik

Siti Sholihatun Mukaromah, I Putu Artaya, SE. MM 
Terhadap Kinerja Pegawai Dengan Kompetensi Sebagai Variabel Intervening (Studi Empiris Pada Pegawai Perusahaan Daerah Air Minum Kabupaten Lebak). Jurnal Riset Bisnis Dan Manajermen Tirtayasa (JRBMT), 1, 1-9.

Marga, Y. K. (2016). Pengaruh Pelatihan, Kecerdasan Emosional, dan Budaya Organisasi Terhadap Kinerja Karyawan Pada PT Pelayaran Tempuran Emas Surabaya, 2, 22-36.

Noermijati. (2013). Kajian Tentang Aktualisasi Teori Herzberg, Kepuasan Kerja dan Kinerja Spiritual Manajer Operasional. Universitas Brawijaya Press.

Pakpahan, E. S., Siswidiyanto, \& Sukanto. (2003). Pengaruh Pendidikan dan Pelatihan Terhadap Kinerja Pegawai (Studi pada Badan Kepegawaian Daerah Kota Malang), 2(1), 116-121.

Pratama, I. B. W., \& Sriathi, A. A. A. (2015). Pengaruh Stres Kerja dan Pemberdayaan Terhadap Kepuasan Kerja Karyawan Di Prama Hotel. E-Jurnal Manajemen Unud, 4(11), 3565-3591.

Putra, S. W. (2015). Pengaruh Komitmen Organisasi, Budaya Organisasi, Gaya Kepemimpinan dan Lingkungan Terhadap Kinerja Karyawan Pada Industri Kecil. Modernisasi, 11, 62-77.

Putri, A. V., \& Ardana, I. K. (2016). Pengaruh Motivasi dan Pemberdayaan Karyawan Terhadap Kinerja Karyawan PT. HD Motor 99 Denpasar, 5(11), 7272-7299.

Sinambela, L. P. (2012). Kinerja Pegawai Teori Pengukuran dan Implikasi. Yogyakarta: Graha Ilmu.

Sunarno, \& Liana, L. (n.d.). Pengaruh Komitmen Organisasional dan Budaya Organisasi Terhadap Kinerja Guru Dimediasi Kepuasan Kerja (Studi Kasus Pada Guru SMA Kesatrian Dalam Yayasan Pendidikan Kesatrian 67), 978-979.

Tanujaya, L. R. (2015). Pengaruh Pelatihan Kerja dan Motivasi Kerja Pada Kinerja Karyawan Departemen Produksi PT. Coronet Crown. Agora, 3(1), 1-7.

Utaminingsih, A. (2014). Perilaku Organisasi. Malang: Universitas Brawijaya Press.

Wibowo. (2007). Manajemen Kinerja. PT. RajaGrafindo Persada.

Widayanti, K. S., \& Sariyathi, N. K. (2016). Pengaruh Kepuasan Kerja, Pemberdayaan Karyawan, dan Stres Kerja Terhadap Komitmen Organisasi Pada CV. Akar Daya Mandiri. E-Jurnal Manajemen Unud, 5(11), 7002-7029.

The Influence of Training, Empowerment, and Organizational Commitment on Employee Performance at PT Rachmat Jaya Sejati Gresik

Siti Sholihatun Mukaromah, I Putu Artaya, SE. MM 